\title{
ANALISIS PENGARUH KEMANFAATAN SISTEM PRESENSI BERBASIS FINGER PRINT TERHADAP KEMUDAHAN BAGI KARYAWAN PADA PT. LUCKY SAMUDRA PRATAMA
}

\author{
Heriyati $^{1}$ \\ Program Studi Sistem Informasi \\ STMIK Nusa Mandiri \\ Jl. Kramat Raya No. 18 Jakarta Pusat 10450, \\ Indonesia \\ E-mail : heriyatiriie@gmail.com
}

\author{
Arfhan Prasetyo ${ }^{2}$ \\ Program Studi Komputer Akuntansi, \\ AMIK Bina Sarana Informatika, \\ J1.Merdeka No.168 (021)8353009, 16114 Indonesia \\ E-mail : arfhan.afp@bsi.ac.id
}

\begin{abstract}
ABSTRAK
Perkembangan Teknologi saat ini menyebabkan kebutuhan akan informasi yang cepat,tepat dan akurat. Salah satu dari perkembangan teknologi diperusahaan adalah Finger Print. PT. Lucky Samudra Pratama adalah salah satu yang menerapkan sistem finger print yang dilakukan secara online dan diharapkan dapat membantu karyawan dalam meningkatkan finger print. Instrumen penelitian mengenai analisis pengaruh kemanfaatan sistem presensi berbasis finger print terhadap kemudahan bagi karyawan pada PT. Lucky Samudra Pratama berupa angket dan objek penelitian adalah karyawan PT. Lucky Samudra Pratama sebanyak 50 responden dari karyawan yang diambil. Analisis data dilakukan dengan teknik analisis deskriptif dengan menggunakan kategori dan persentase melalui skala Likert. Hasil penelitian menunjukkan bahwa hubungan yang terjadi antara variabel X (Persepsi terhadap kemanfaatan) dengan variabel Y (Persepsi Kemudahan Pemakai) dalam pengaruh sistem finger print pada PT. Lucky Samudra Pratama adalah 2427,062 . Nilai korelasi sebesar ini sangat kuat positif. Hubungan bersifat positif artinya terjadi hubungan searah antara variabel $\mathrm{X}$ dan variabel $\mathrm{Y}$.
\end{abstract}

\section{ABSTRACT}

The development of the technology this caused the need for rapid information, Precisely and accurately. One of technological development company was the finger print. PT.Lucky Samudra Pratama is one of the implemented the system of the finger print conducted in online and is expected to help an employee in increase the finger print. An instrument research on analysis influence benefit presensi system based the finger print to facilities for employees at PT.Lucky Samudra Pratama In the form of such research and the object of whom are employees PT.Lucky Samudra Pratama As many as 50 respondents employees taken. Analysis of data was undertaken to technique descriptive analysis by the use of category and the percentage through likert scale. The result showed that relationship happened between variable $x$ ( perspective on significance) with variable $y$ ( perception ease) users in the grip of the finger print system in PT. Lucky Samudra Pratama 2427,062. The correlation value is as much as is quite strong showed signs of positive sentiments. Relationship is positive it means happened relations in line between variables $x$ and variable $y$.

Key Word: influence, facility, Presensi System, Finger Print .

\section{Pendahuluan}

\subsection{Latar Belakang Masalah}

Dalam perkembangan ilmu pengetahuan dan teknologi dewasa ini,menjadian informasi memiliki peranan yang sangat penting dalam usaha menciptakan kemajuan disemua bidang kehiduapan manusia. Dengan adanya teknologi informasi telah banyak dirasakan kemudahan dalam mendapatkan informasi yang cepat,tepat dan akurat. Perkembangan teknologi informasi pada saat ini sangat pesat, sehingga setiap manusia membutuhkan komputer dalam mengerjakan setiap pekerjaannya. 
Komputer memiliki peranan yang sangat baik dalam pemecahan masalah khusus dalam pengelolaan data, karena komputer memiliki kecepatan tingkat akurasi yang tinggi dalam pemrosesan data, sehingga dapat mempermudah pekerjaan setiap manusia. Adanya sistem komputer sangat membantu dalam pemecahan masalah terutama dalam hal pengolahan data apapun terutama sistem presensi karyawan yang akan kami bahas disini. Pengunaan komputer juga dapat dijadikan alat untuk mencapai tujuan dan mencari kemudahan dalam melakukan suatu proses pekerjaan, terutama yang melibatkan banyak data. Hampir disemua instansi-instansi baik yang bersifat negeri maupu swasta menggunakan sistem komputer, bahkan usaha-usaha kecil, menengahpun sudah memanfaatkan keberadaan sistem komputer.

PT. Lucky Samudra Pratama merupakan perusahaan yang menggunakan sistem absensi secara manual sebalum adanya sistem finger print, dan diharapkan dapat membantu karyawan dalam meningkatkan mereka yaitu dapat memudahkan karyawan dalam memahaminya.

Dewi Larasatri (2016:2), Sistem presensi sidik jari terbukti mampu mengurangi kecurangan dan manipulasi data dalam merekam kehadiran pegawai. Hal ini dikarenakan data langsung terekam secara otomatis di mesin sidik jari dan hanya dapat dibuka oleh seorang operator yang ditunjuk. Artinya bahwa hanya orang tertentu (yang ditugasi) saja yang berhak membuka database presensi tersebut. Dengan demikian tidak semua orang dapat memanipulasi data presensi tersebut. Sejak diberlakukannya sistem informasi presensi sidik jari secara online belum pernah dikaji bagaimana korelasi antara implementasi sistem informasi presensi sidik jari dan kedisiplinan pegawai terhadap perubahan perilaku kerja pegawai.

Sistem informasi sendiri adalah suatu jaringan kerja yang merupakan kumpulan dari elemen-elemen yang saling berhubungan dan berintreraksi untuk mencapai tujuan tertentu yaitu berupa informasi yang diperlukan dalam mengambil keputusan baik untuk waktu sekarang maupun diwaktu yang akan datang.

Informasi dan data merupakan komponen yang saling berhubungan satu sama lain. Informasi merupakan hasil dari pengolahan data yang member arti dan bermanfaat sedangkan data adalah fakta atau apapun yang bisa atau dapat digunakan sebagai input dalam menghasilkan informasi yang berkualitas.

Dari latar belakang di atas, maka penulis ingin melakukan penelitian untuk dijadikan bahan untuk Skripsi. Dan peneliti memberikan judul pada peneliti ini "Analisis Pengaruh Kemanfaatan sistem Presensi berbasis Finger Print terhadap Kemudahan bagi karyawan pada PT. Lucky Samudra Pratama".

\subsection{Identifikasi Masalah}

Berdasarkan latar belakang di atas, maka dalam penelitian ini ada beberapa hal yang dapat diidentifikasikan yaitu:

1. Menjelaskan pengaruh persepsi terhadap kemanfaatan (perceived usefulness). Kemudahan pemakai (perceived ease of use) terhadap penggunaan sistem finger print bagi karyawan PT. Lucky Samudra Pratama.

2. Menjelaskan faktor-faktor yang dapat mendorong karyawan PT. Lucky Samudra Pratama dalam menggunakan sistem finger print.

3. Mengetahui hasil dari penelitian tersebut dengan menggunakan Technology Acceptance Model (TAM) dan tools yang digunakan adalah SPSS 16

\subsection{Maksud dan Tujuan}

Maksud dari penulisan skripsi ini adalah sebagai berikut:

1. Untuk mengetahui dan mengatur hubungan persepsi terhadap kemanfaatan (perceived usefulness), dan kemudahan pemakai (perceived ease of use) terhadap penggunaan sistem finger print karyawan PT. Lucky Samudra Pratama.

1. Untuk mengetahui faktor-faktor yang mendorong karyawan PT. Lucky Samudra Pratama dalam menggunakan sistem finger print.

Dan tujuan dari penulis skripsi ini adalah sebagai salah satu sayarat kelulusan Strata Satu (S1) pada Sekolah Tinggi Manajemen Informatika dan Komputer STMIK Nusa Mandiri Jakarta.

\section{Landasan Teori}

\subsection{TAM}

TAM menambahkan dua konstruk utama ke dalam model TRA. Dua konstruk utama ini 
adalah kegunaan persepsian (perceived usefulness) dan kemudahan pengguna persepsian (perceived ease of use). TAM beragumentasi bahwa penerimaan individual terhadap sistem teknologi informasi ditentukan oleh dua konstruk tersebut. Kegunaan persepsian (perceived usefulness) dan kemudahan penggunaan persepsian (perceived ease of use) keduanya mempunyai pengaruh ke niat perilaku (behavioral intention). Pemakai teknologi akan mempunyai niat menggunakan teknologi (niat perilaku) jika merasa sistem teknologi bermanfaat dan mudah digunakan. (Jogiyanto,2008:111-112)

Jogiyanto (2008:113-117)Technology Acceptance Model (TAM) yang pertama sebelum dimodifikasi menggunakan lima konstruk utama.

Kelima konstruk ini adalah sebagai berikut:

1. Kegunaan persepsian (perceived usefulness) Sejauh mana seseorang percaya bahwa menggunakan suatu teknologi akan meningkatkan kinerja pekerjaannya.

2. Kemudahan penggunaan persepsian (perceived ease of use)

Sejauh mana seseorang percaya bahwa menggunakan suatu teknologi akan bebas dari usaha.

3. Sikap terhadap perilaku (attitide towards behavior)

Perasaan - perasaan positif dan negatif dari seseorang jika harus melakukan perilaku yang akan ditentukan.

4. Niat Perilaku (behavior intention)

Suatu keinginan (niat) seseorang untuk melakukan suatu perilaku yang tertentu. Seseorang akan melakukan suatu perilaku (behavior) jika mempunyai keinginan atau niat (behavior intention) untuk melakukannya.

5. Perilaku (behavior)

Tindakan yang dilakukan oleh seseorang. Dalam konteks penggunaan sistem teknologi informasi, perilaku (behavior) adalah penggunaan sesungguh - sesungguhnya (actual use) dari teknologi.

\subsection{IBM SPSS 23}

Ghozali (2013:15) SPSS adalah kepanjangan dari Statistical Package for Social Sciences yaitu software yang berfungsi untuk menganalisis data, melakukan perhitungan statistika baik untuk statistik parametrik maupun non-parametrik dengan basis windows. Versi software SPSS secara terus-menerus mengalami perubahan. Saat sistem operasi komputer windows mulai popular, SPSS yang dahulunya under DOS dan bernama SPSS PC, juga berubah menjadi under windows dan populer di indonesia dengan SPSS Versi 6, kemudian versi 7.5, versi 9, versi 10, versi 11.5 , versi 12 , versi 13 , versi 14 , versi 15 , versi 16 , versi 17 , versi 18 , dan terakhir lisensinya dibeli oleh IBM dan diberi nama IBM SPSS versi 23 adalah versi yang terakhir.

\section{Metode Penelitian}

\subsection{Instrumen Penelitian}

Sugiyono (2010:102) berpendapat bahwa, "Instrumen penelitian adalah suatu alat yang digunakan mengukur fenomena alam maupun sosial yang diamati. Secara spesifik semua fenomena ini disebut variabel penelitian".

Instrumen penelitian sangat berperan penting dalam keberhasilan suatu penelitian. Karena data yang diperlukan untuk menjawab permasalahan yang diteliti diperoleh melalui instrumen penelitian.

\subsection{Metode Pengumpulan Data, Populasi dan Sample Penelitian}

Metode pengumpulan data yang penulis lakukan dalam penelitian skripsi ini sebagai berikut:

1. Observasi

Penelitian ini dilakukan secara langsung, yaitu dengan datang langsung ke PT. Lucky Samudra Pratama. Penelitian ini mulai dilaksanakan pada tanggal 01 Desember 2017 - 10 Desember 2017. Adapun metode dalam pengumpulan data penelitian ini dengan menggunakan metode penyebaran kuesioner mengenai evaluasi sistem finger print yang diberikan langsung kepada karyawan yang menggunakan sistem finger print.

2. Studi Pustaka

Penulis mendapat data yang bersifat teoritis yang berhubungan dengan skripsi ini yang membahas tentang evaluasi sistem finger print, yang diperoleh dengan cara mempelajari jurnal - jurnal penelitian, internet dan buku yang dijadikan bahan pertimbangan sebagai referensi untuk acuan.

3. Wawancara

Penelitian ini dilakukan dengan mewawancarai narasumber secara langsung, yaitu dengan datang langsung ke PT. Lucky Samudra Pratama dan melakukan wawancara dengan Manager perusahaan. 
Populasi dalam penelitian ini adalah karyawan PT. Lucky Samudra Pratama.

\subsection{Perhitungan Koefisien Korelasi Person Product Moment}

Siregar (2014:338) berpendapat bahwa, "Korelasi Person Product Moment adalah untuk mencari hubungan variabel bebas (X) dengan variabel tak bebas (Y), dan data berbentuk interval dan rasio".

Siregar (2010:164) berpendapat suatu instrumen dikatakan valid, bila :

1. Jika koefisien korelasi Person Product Moment melebihi 0,3

2. Jika koefisien korelasi Person Product Moment $>$ $\mathrm{r}$ - tabel $(\alpha ; \mathrm{n}-2), \mathrm{n}=\mathrm{jumlah}$ sample.

3. Nilai Sig. $s \alpha$

Rumus yang bisa digunakan untuk uji validalitas menggunakan teknik korelasi Person Product Moment adalah:

$$
r=\frac{n\left(\sum x y\right)-\left(\sum x\right)\left(\sum y\right)}{\sqrt{\left[n \sum x^{2}-\left(\sum x\right)^{2}\right] \sqrt{\left[n \sum y^{2}-\left(\sum y\right)^{2}\right]}}}
$$

Keterangan:

$\mathrm{n}=$ jumlah data (50 responden)

$\mathrm{x}=$ variabel bebas

$\mathrm{y}=$ variabel terkait

\subsection{Koefisien Korelasi Person Product}

\section{Moment}

adalah untuk mencari hubungan variabel bebas (X) dengan variabel tak bebas (Y), dan data berbentuk interval dan rasio".

Tabel 3.1 Contoh penolong untuk mencari Nilai Korelasi Sederhana

\begin{tabular}{|c|c|c|c|c|c|}
\hline $\begin{array}{c}\text { Data } \\
(\mathrm{n})\end{array}$ & $\begin{array}{c}\text { Vari } \\
\text { abel } \\
\text { beba } \\
\text { s (X) }\end{array}$ & $\begin{array}{c}\text { Varia } \\
\text { bel } \\
\text { tak } \\
\text { bebas } \\
(Y)\end{array}$ & XY & $X^{2}$ & $Y^{2}$ \\
\hline 1 & $\ldots$ & $\ldots$ & $\ldots$ & $\ldots$ & $\ldots$ \\
\hline 2 & $\ldots$ & $\ldots$ & $\ldots$ & $\ldots$ & $\ldots$ \\
\hline 3 & $\ldots$ & $\ldots$ & $\ldots$ & $\ldots$ & $\ldots$ \\
\hline$\ldots$ & $\ldots$ & $\ldots$ & $\ldots$ & $\ldots$ & $\ldots$ \\
\hline
\end{tabular}

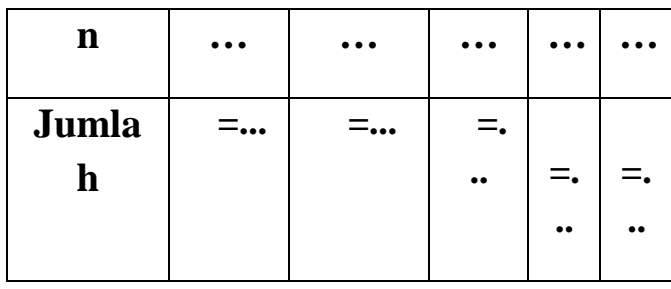

\subsection{Regresi Linear Sederhana}

Salah satu alat yang dapat digunakan dalam memprediksi permintaan di masa yang akan datang dengan berdasarkan data masa lalu, atau untuk mengetahui pengaruh satu variabel bebas (independent) terhadap satu variabel tak bebas (dependent) adalah menggunakan regresi linier Rumus regresi linear sederhana, yaitu:

$$
\mathbf{Y}=\mathbf{a}+\mathbf{b} \cdot \mathbf{X}
$$

Keterangan:

$\mathrm{Y} \quad=$ variabel terikat

$\mathrm{X}=$ variabel bebas

$\mathrm{a}=$ konstanta

$\mathrm{b} \quad=$ konstanta

\section{Hasil dan Pembahasan \\ 4.1 Uji Validitas manual}

Tabel IV.11

\begin{tabular}{|c|c|c|c|}
\hline $\begin{array}{l}\text { Butir } \\
\text { Perta } \\
\text { nyaan }\end{array}$ & $\begin{array}{c}\mathbf{r}_{\text {hitu }} \\
\mathbf{n g}\end{array}$ & $\begin{array}{l}\mathbf{r}_{\text {ta }} \\
\text { bel }\end{array}$ & $\begin{array}{c}\text { Keputu } \\
\text { san }\end{array}$ \\
\hline X1 & $\begin{array}{l}0,7 \\
00\end{array}$ & $\begin{array}{c}0, \\
28 \\
4\end{array}$ & Valid \\
\hline X2 & $\begin{array}{l}0,7 \\
81\end{array}$ & $\begin{array}{c}0 \\
28 \\
4\end{array}$ & Valid \\
\hline X3 & $\begin{array}{c}0,7 \\
00\end{array}$ & $\begin{array}{c}0, \\
28 \\
4\end{array}$ & Valid \\
\hline $\mathrm{X} 4$ & $\begin{array}{c}0,3 \\
14\end{array}$ & $\begin{array}{c}0, \\
28 \\
4\end{array}$ & Valid \\
\hline
\end{tabular}

Hasil perhitungan uji validitas secara 


\begin{tabular}{|c|c|c|c|}
\hline X5 & $\begin{array}{c}0,5 \\
60\end{array}$ & $\begin{array}{c}0, \\
28 \\
4\end{array}$ & Valid \\
\hline Y1 & $\begin{array}{c}0,6 \\
16\end{array}$ & $\begin{array}{c}0, \\
28 \\
4\end{array}$ & Valid \\
\hline Y2 & $\begin{array}{r}0,5 \\
36\end{array}$ & $\begin{array}{c}0, \\
28 \\
4\end{array}$ & Valid \\
\hline Y3 & $\begin{array}{c}0,4 \\
97\end{array}$ & $\begin{array}{c}0, \\
28 \\
4\end{array}$ & Valid \\
\hline Y4 & $\begin{array}{r}0,7 \\
70\end{array}$ & $\begin{array}{c}0, \\
28 \\
4\end{array}$ & Valid \\
\hline Y5 & $\begin{array}{c}0,5 \\
31\end{array}$ & $\begin{array}{c}0, \\
28 \\
4\end{array}$ & Valid \\
\hline
\end{tabular}

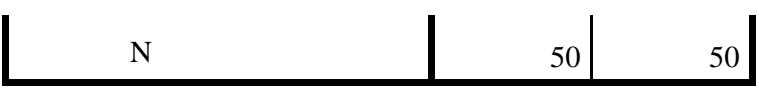

\subsection{Descriptive Statistics}

Tabel IV.16

Descriptive Statistics

\begin{tabular}{|l|r|r|r|}
\hline & \multicolumn{1}{|c|}{ Mean } & \multicolumn{1}{|c|}{ Std. Deviation } & $\mathrm{N}$ \\
\hline $\mathrm{Y}$ & 18,32 & 2,676 & 50 \\
$\mathrm{X}$ & 19,80 & 1,884 & 50 \\
\hline
\end{tabular}

\section{Kesimpulan}

Dari hasil analisis data yang dilakukan, didapatkan kesimpulan sebagai berikut :

1. Berdasarkan analisis hubungan koefisein korelasi, baik secara manual maupun menggunakan SPSS, dapat disimpulkan bahwa hubungan yang terjadi antara variabel $\mathrm{X}$ (Persepsi terhadap Kemanfaatan) dengan variabel Y (Persepsi Kemudahan Pemakai) dalam penggunaan sistem finger print PT. Lucky Samudra Pratama adalah 2427,062. Nilai korelasi sebesar ini adalah kuat positif. Hubungan bersifat kuat positif artinya terjadi hubungan searah antara variabel $\mathrm{X}$ dan variabel Y. Bila Kemanfaatan semakin baik maka Kemudahan Pemakai semangkin meningkat.

2. Kontribusi pengaruh variabel $\mathrm{X}$ (Kemanfaatan) dengan variabel Y (Kemudahan Pemakai) dalam penggunaan sistem finger print PT. Lucky Samudra Pratama adalah 589062995,2.

3. Hasil pengujian signifikansi (Korelasi Product Moment Person) didapat nilai $t_{\text {hitung }}=5890629$, dengan taraf signifikansi $5 \%$ maka nilai $\mathrm{t}_{\text {tabel }}=$ 20128956. Karena $t_{\text {hitung }}$ lebih kecil dari $t_{\text {tabel }}$ maka Ho diterima, sehingga $\mathrm{H}_{1}$ ditolak. Dengan demikian tidak ada pengaruh yang signifikan antara kemanfaatan dan kemudahan pemakai terhadap penggunaan sistem finger print PT. Lucky Samudra Pratama.

4. Faktor-faktor yang mendorong karyawan PT. Lucky Samudra Pratama dalam menggunakan sistem finger print ini, yaitu:

a. Faktor Kemanfataan yaitu banyaknya manfaat yang di peroleh karyawan dari sistem finger print. 
b. Faktor kemudahan pemakai yaitu kemudahan karyawan dalam mengakses dan menggunakan sistem finger print.

\section{DAFTAR PUSTAKA}

Larasatri, D. (2016). Korelasi Implementasi Sistem Presensi Sidik Jari (Fingerprint) Online dan Kedisiplinan terhadap Perubahan Perilaku Kerja Pegawai. Jurnal Strategi dan Bisnis Vol.4, No. 1 April 2016. Diambil dari: http://repository.unej.ac.id/handle/123 456789/79146. (09 Oktober 2017)

Mulyanto, Agus. (2009). Sistem Informasi Konsep dan Aplikasi. Yogyakrta: Pustaka Pelajar

Fatta, Hanif Al. (2007). Analisis dan Perancangan Sistem Informasi. Yogyakarta: Andi Publisher

Jogiyanto. 2(008). Sistem Informasi Keperilakuan. Yogyakarta: Andi

Ghozali, Imam. (2013). Aplikasi Analisis Multivariete: Dengan Menggunakan IBM SPSS 23. Semarang: Badan Penerbit Universitas Diponegoro

Yuliandewi, P. R., Agustini, K., Si, S., Si, M., \& Pradnyana, I. M. A. (2016). Analisis Penerimaan Sistem Absensi Wajah dengan Menggunakan Technology Acceptance Model (TAM) Studi Kasus: SMK NEGERI 1 SINGARAJA. Karmapati (Kumpulan Artikel Mahasiswa Pendidikan Teknik Informatika) ISSN: 2252-9063, 5(2). Diambil dari:
http://ejournal.undiksha.ac.id\%2Findex.

Desember 2017)

Indarti, I. (2016). Pengaruh Efektivitas Penerapan Sistem Presensi Terpadu Fingerprint Terhadap Disiplin Kerja Pegawai Negeri Sipil (Studi Kasus: Dinas Pemadam Kebakaran Lebak Bulus Jakarta Selatan). Jurnal Sistem Informasi, 5(2), 121-128. Diambil dari:

http://ejournalab.com\%2Findex.(

Sugiyono. (2010). Metode Penelitian Kuantitatif, Kualitatif dan R\&D. Bandung: Alfabeta

Noviandini, N. C. (2012). Pengaruh Persepsi Kebermanfaatan, Persepsi Kemudahan Penggunaan, Dan Kepuasan Wajib Pajak Terhadap Penggunaan E-Filing Bagi Wajib Pajak Di Yogyakarta. Nominal: Barometer Riset Akuntansi Dan Manajemen, 1(1). Diambil dari:

http://journal.uny.ac.id\%2Findex. $(05$ januari 2018)

Riduwan. (2010). Sakala Pengukuran Variabelvariabel Penelitian. Bandung: Alfabeta

Siregar, Syopian. (2010). Statistika Deskriptif Untuk Penelitian: Dilengkapi Perhitungan Manual dan Aplikasi SPSS Versi 17. Jakarta: Rajawali Pers

Siregar, Syopian. (2014). Statistik Parameter Untuk Penelitian Kuantitatif: Dilengkapi Perhitungan Manual dan Aplikasi SPSS Versi 17. Jakarta: Bumi Aksara 